\title{
The effects of climate on decomposition of cattle, sheep and goat manure in Kenyan tropical pastures
}

\author{
Yuhao Zhu • Lutz Merbold - Sonja Leitner - David E. Pelster • \\ Sheila Abwanda Okoma • Felix Ngetich • Alice Anyango Onyango • Petri Pellikka • \\ Klaus Butterbach-Bahl
}

Received: 20 January 2020 / Accepted: 6 April 2020/Published online: 25 April 2020

(C) The Author(s) 2020

\begin{abstract}
Aims Decomposition of manure deposited onto pasture from grazing animals represents an important process for carbon (C) and nitrogen $(\mathrm{N})$ cycles in grassland systems. However, studies investigating manure
\end{abstract}

Responsible Editor: Zucong Cai.

Electronic supplementary material The online version of this article (https://doi.org/10.1007/s11104-020-04528-x) contains supplementary material, which is available to authorized users.

Y. Zhu $\cdot$ K. Butterbach-Bahl

Institute of Meteorology and Climate Research, Atmospheric Environmental Research (IMK-IFU), Karlsruhe Institute of Technology (KIT), Kreuzeckbahnstr. 19,

82467 Garmisch-Partenkirchen, Germany

Y. Zhu

e-mail: Yuhao.zhu@kit.edu

Y. Zhu · L. Merbold · S. Leitner · D. E. Pelster •

S. A. Okoma · A. A. Onyango · K. Butterbach-Bahl $(\bowtie)$ Mazingira Centre, International Livestock Research Institute (ILRI), P.O. Box 30709, Nairobi 00100, Kenya

e-mail: Klaus.butterbach-Bahl@kit.edu

L. Merbold

e-mail: 1.merbold@cgiar.org

\section{S. Leitner}

e-mail: s.leitner@cgiar.org

D. E. Pelster

e-mail: david.pelster@canada.ca decomposition are scarce; especially in sub-Saharan Africa (SSA).

Methods In this study, we measured decomposition of three types of animal manure (cattle, sheep, goat) over $>1$ year using litter bags at four climatically different

S. A. Okoma

e-mail: s.okoma@cgiar.org

A. A. Onyango

e-mail: onyangoalice@gmail.com

F. Ngetich

Department of Land and Water Management, University of Embu, P.O. Box 6-60100, Embu, Kenya

e-mail: felixngetich@yahoo.com

P. Pellikka

Earth Change Observation Laboratory, Department of

Geosciences and Geography, University of Helsinki, Helsinki,

Finland

e-mail: petri.pellikka@helsinki.fi

P. Pellikka

Institute for Atmospheric and Earth System Research, University of Helsinki, Helsinki, Finland

Present Address:

D. E. Pelster

Agriculture and Agri-Food Canada, 2560 Blvd Hochelaga, QC, Quebec, Canada 
sites across Kenya. Results Manure dry matter, total C, total $\mathrm{N}$ and ammonium concentrations decreased exponentially, with the most rapid decrease occurring during the first few weeks following application, followed by slower changes during the following $2-3$ months. Rates of $\mathrm{N}$ mineralization were lower than those for $\mathrm{C}$ mineralization, resulting in decreasing $\mathrm{C} / \mathrm{N}$ ratios over time. Generally, cattle manure decomposed faster than sheep or goat manure despite having a higher initial $\mathrm{C} / \mathrm{N}$ ratio and lower $\mathrm{N}$ concentration, with decomposition rates for dry matter ranging from 0.200 to $0.989 k$ year $^{-1}$. Cellulose decomposed first, while lignin concentrations increased among all manure types and at all sites.

Conclusions We found that total manure decomposition rates were positively correlated with cumulative precipitation and aridity index, but negatively correlated with mean temperature. Our results show much slower decomposition rates of manures in semi-arid tropical environments of East Africa as compared to the few previous studies in temperate climates.

Keywords Litter bags · Manure - Mineralization . Climatic conditions · Sub-Saharan Africa (SSA) · Cellulose $\cdot$ Lignin

\section{Introduction}

Decomposition is a critical ecosystem function (Wilkinson 2006) that is fundamental to nutrient, carbon (C) and energy cycling within and among ecosystems, and between the biosphere and atmosphere (Schlesinger and Bernhardt 2013; Wieder et al. 2013). More than half of net primary production (NPP) is returned to the soil through litter decomposition (David et al. 2004), while it also results in $\mathrm{CO}_{2}$ emissions to the atmosphere of about $60 \mathrm{Pg}$ $\mathrm{C} \mathrm{yr}^{-1}$ (Houghton 2007). Internal recycling of nitrogen $(\mathrm{N})$ from litter decomposition is also the primary source of $\mathrm{N}$ for most ecosystems (Parton et al. 2007; Chapin et al. 2011).

Decomposition largely results from the activities of soil microorganisms and macrofauna, which break down complex non-living organic matter (e.g. protein, cellulose) into smaller oligo- and monomers (e.g. amino acids, sugars) to gain energy and matter to build and maintain their biomass (Handa et al. 2014; Bradford et al. 2016). This process can be divided into two stages: The early decomposition stage, during which up to $40 \%$ of mass is lost, is characterized by leaching of soluble compounds and decomposition of soluble and nonlignified cellulose and hemicellulose. The late stage comprises the degradation of lignified tissue, which accounts for $40-100 \%$ of mass loss (Heim and Frey 2004). Litter decomposition rates are driven by multiple biotic and abiotic factors such as litter quality (GarcíaPalacios et al. 2016a; Prieto et al. 2019), decomposer community (Wang et al. 2009; Allison et al. 2013; Matulich and Martiny 2015), and climatic factors, including temperature and moisture (Wang et al. 2010; Veen et al. 2015; Bradford et al. 2016), with warmer and wetter conditions leading to faster decomposition (Coûteaux et al. 1995; Aerts 1997). Litter quality including initial $\mathrm{N}$ concentration, $\mathrm{C} / \mathrm{N}$ ratio and lignin concentration is the predominant factor controlling decomposition through regulating decomposer activities under a given climatic condition (Hishinuma et al. 2017; Pei et al. 2019). Decomposition in natural ecosystems is synchronized with plant growth, while anthropogenic disturbance may retard or accelerate decomposition rates in managed ecosystems (Banegas et al. 2015).

Grasslands are the largest terrestrial ecosystem type, covering up to $40 \%$ (59 million $\mathrm{km}^{2}$ ) of the world's ice-free land area (Hufkens et al. 2016), with most grasslands used for grazing of livestock (Salvati and Carlucci 2015; Zhou et al. 2018). Grazing animals consume large amounts of biomass that often reduce litter inputs to soil (Güsewell et al. 2005; Tanentzap and Coomes 2012). Plants ingested by grazing animals are fragmented and digested in their gut before being deposited onto the soil surface. Thereby approximately $75 \%$ of ingested $\mathrm{N}$ by grassfed animals is returned to the soil as excreta (Oenema et al. 2005).

Excreta has high concentrations of easilydecomposable $\mathrm{C}$ and $\mathrm{N}$ compounds, providing readilyaccessible nutrients to soil micro- and macrobiota and plants that may lead to accelerated decomposition rates as compared to plant litter (Knops et al. 2002; Bakker et al. 2004). Adult cattle can excrete up to $25 \mathrm{~kg}$ fresh dung and $21 \mathrm{~L}$ urine per day (Haynes and Williams 1993), while goats and sheep generally produce much less excreta, but with higher nutrient concentrations that tend to be more widely distributed (Bakker et al. 2004). In general, $5 \%$ and $20 \%$ of pasture surface area are estimated to receive either dung or urine, respectively, every year (Moir et al. 2011; Ward et al. 2018). 
Driven by the increasing demand for livestock products it is expected that global cattle populations will increase from 1.5 billion to 2.6 billion and that of goat and sheep from 1.7 billion to 2.7 billion by 2050 (FAO 2009), which will change the volume and likely the type of manure deposited on pasture when herd composition changes. Considering the grazing area and number of livestock, manure plays a major role in $\mathrm{C}$ and $\mathrm{N}$ cycling in grassland ecosystems. However, quality differences in manure between different animal species may result in differences in decomposition processes and $\mathrm{C}$ and $\mathrm{N}$ mineralization rates, which in turn might affect $\mathrm{C}$ and $\mathrm{N}$ cycling in grasslands.

Savanna ecosystems cover about $65 \%$ of the African continent (Brümmer et al. 2008), with much of this area being used by livestock farmers. In much of the arid and semi-arid regions in sub-Saharan Africa (SSA), livestock production generally relies on grazing of native pasture (Thornton and Herrero 2014) with long free grazing time, which leads to more than $40 \%$ of total excreta being deposited on rangelands without further use or management (Rufino et al. 2006). As soils in grazing areas across SSA are often highly weathered and depleted of $\mathrm{N}$, dung and urine play a major role in replenishing $\mathrm{C}$ and $\mathrm{N}$ pools, which is crucial in maintaining land productivity (Powell et al. 1996). However, studies investigating animal manure decomposition and $\mathrm{C}$ and $\mathrm{N}$ mineralization in tropical ecosystems and especially in SSA are scarce.

To provide information on how animal manure decomposition affects nutrient cycling in tropical pasture systems, we measured decomposition rates and changes in manure chemistry of three types of manure at four climatically different sites across Kenya for $>1$ year (378 days). The objectives were to 1 ) measure changes in manure $\mathrm{C}$ and $\mathrm{N}$ concentrations over time after manure deposition; 2) determine if manure type (i.e. animal species) affects manure decomposition rates; and 3) determine how climate affects manure decomposition. We hypothesized that 1) manure decomposition rates would be faster for manure with lower initial $\mathrm{C} / \mathrm{N}$ ratios and higher initial $\mathrm{N}$ concentrations; 2) manure would decompose faster under wetter and warmer climatic conditions; and 3 ) that $\mathrm{C} / \mathrm{N}$ ratios in decomposing manure would decrease over time due to slower decomposition of complex N-rich compounds like lignin.

\section{Materials and methods}

\section{Site description}

For our study, four sites with different climatic conditions in Kenya were selected. As shown in Table 1, the four sites were: Maktau in the Taita-Taveta county in South Kenya (Taita); the research campus of the International Livestock Research Institute in Nairobi (ILRI); Kapiti Research Station in Machakos county in South Central Kenya (Kapiti), and Machanga in Embu county in Central Kenya (Embu) (Table 1). The long-term mean annual precipitation rates were lowest at the southernmost site (Taita) and highest at the northernmost site (Embu) (Table 1). Mean annual temperatures ranged from 19.0 to $25.0{ }^{\circ} \mathrm{C}$, with the warmer temperatures associated with the lower elevation sites and cooler temperatures at higher elevation sites.

\section{Experimental design}

Approximately $100 \mathrm{~g}$ of fresh cattle manure, $70 \mathrm{~g}$ of fresh sheep manure and $30 \mathrm{~g}$ of fresh goat manure were weighed and put into individual $12.5 \mathrm{~cm} \times 10 \mathrm{~cm} \mathrm{1-mm}$ nylon mesh bags. Prior measurement of manure water content showed that this is equivalent to approximately $20 \mathrm{~g}$ of manure dry matter (DM), though actual DM contents were finally measured for each sample. The litter bags allow for water, nutrient and microbial passage, while preventing soil macrofauna (e.g. termites) from entering, and have been used widely in decomposition studies (García-Palacios et al. 2016b). Fresh cattle dung was collected at the ILRI Nairobi farm from a cattle herd that grazed on pasture during the day and was housed in single-animal pens at night. Goat and sheep also grazed on the same pasture during the day, but were taken back to a communal barn with a concrete floor overnight, where the manure was collected the following morning. Although the manure was collected from the same source, manure properties differed across different collection days. Consequently, only manure for the Kapiti and Embu sites, which was sampled on the same day, showed the same initial properties, while manure properties for the other two sites differed slightly (Table 2).

Due to logistical reasons, the manure was stored at $4{ }^{\circ} \mathrm{C}$ for up to two days before being placed in the nylon bags and transported to the various locations, where the litter bags were laid on the soil. For each 
Table 1 Overview of location of sites (name, coordinates, county), altitude, long-term mean annual precipitation and air temperature and aridity index during our observation period at a given site. Aridity index was calculated using the following equation: Aridity index $=$ precipitation $/$ potential evapotranspiration

\begin{tabular}{|c|c|c|c|c|c|c|c|}
\hline Site & Coordinates & County & Altitude (m) & $\begin{array}{l}\text { Mean annual } \\
\text { precipitation }(\mathrm{mm})\end{array}$ & $\begin{array}{l}\text { Mean annual } \\
\text { temperature }\left({ }^{\circ} \mathrm{C}\right)\end{array}$ & Aridity index & References \\
\hline Taita & S $3^{\circ} 25^{\prime}$ E $38^{\circ} 20^{\prime}$ & Taita Taveta & 700 & $400-600$ & 25.0 & 0.18 & Pellikka et al. (2018) \\
\hline ILRI & $\mathrm{S} 1^{\circ} 16^{\prime} 13^{\prime \prime} \mathrm{E} 36^{\circ} 43^{\prime} 23^{\prime \prime}$ & Nairobi & 1809 & 869 & 19.0 & 0.92 & Pelster et al. (2016) \\
\hline Kapiti & S $1^{\circ} 37^{\prime} 06^{\prime \prime}$ E $37^{\circ} 06^{\prime} 09^{\prime \prime}$ & Machakos & 1600 & 550 & 20.2 & 0.37 & \\
\hline Embu & S $0^{\circ} 46^{\prime}$ E $37^{\circ} 39^{\prime}$ & Embu & 1100 & $700-900$ & $20.7-22.5$ & 0.12 & Ngetich et al. (2014) \\
\hline
\end{tabular}

of the four sites 207 nylon bags were prepared, i.e. 828 bags in total ( 3 manure types $\times 3$ replicates $\times 23$ sampling dates $\times 4$ sites). Subsamples of the dung were frozen for nutrient analyses. The manure bags were applied to the pasture on 31 March, 06 April, 11 April and 12 April, 2018 for the Taita, ILRI, Kapiti and Embu sites, respectively.

At each site, an open and flat area $(2.5 \mathrm{~m} \times 6.0 \mathrm{~m})$ was chosen and the grass on the surface was cut with scissors at the ground level. Manure bags were placed on the soil surface. After application, three bags for each manure type were sampled from each site once per week for the first seven weeks of the experiment as we expected high initial decomposition rates. After the initial seven-week period, sampling occurred bi-weekly during the rainy seasons and monthly in the dry seasons to assure that major decomposition events were not missed. In total, there were 23 sampling dates over a 378-day period for each of the four sites.

Environmental data

Weather stations were installed at each site to collect meteorological data (rainfall and air temperature at all sites, soil temperature and soil moisture at Taita, ILRI and Embu), during the course of the experiment. The climate data were downloaded at least in monthly intervals. PMday.xls was used to calculate daily reference evapotranspiration (ETref) rates using the Penman-Monteith equation as presented by the Environmental Water Resources Institute (EWRI) American Society of Civil Engineers Committee (ASCE) on Reference Evapotranspiration (ASCE-EWRI 2004). For further details see http://biomet.ucdavis. edu/Evapotranspiration/PMdayXLS/PMday.htm.
Manure analysis

At each sampling date, the surfaces of the collected bags were cleaned carefully with a brush to remove attached vegetation or soil particles before opening the bag followed by measuring the fresh weight of the manure remaining inside the bag. A $5 \mathrm{~g}$ sub-sample was ovendried at $50{ }^{\circ} \mathrm{C}$ until constant weight and ground for total $\mathrm{C}$ and $\mathrm{N}$ analysis with an elemental combustion system (Vario max cube, Elementar analysensysteme $\mathrm{GmbH}$, Germany). Ammonium $\left(\mathrm{NH}_{4}{ }^{+}\right)$and nitrate $\left(\mathrm{NO}_{3}{ }^{-}\right)$were extracted from the manure sample by mixing a $1 \mathrm{~g}$ subsample with $25 \mathrm{ml} 1 \mathrm{M} \mathrm{KCl}$ in a $50 \mathrm{ml}$ plastic bottle, shaking the slurry on a reciprocal shaker for $1 \mathrm{~h}$, centrifuging at $3000 \mathrm{rpm}$ for $10 \mathrm{~min}$ and filtering (Whatman No. 42) the supernatant. Extracts were then frozen until colorimetric analyses for $\mathrm{NH}_{4}{ }^{+}$and $\mathrm{NO}_{3}{ }^{-}$ concentrations (Hood-Nowotny et al. 2010). The rest of the manure was then weighed and oven-dried at $105^{\circ} \mathrm{C}$ for $24 \mathrm{~h}$ for determination of water content. Cellulose, hemicellulose, lignin and crude protein $(\mathrm{CP})$ concentrations were measured at time zero, at week 27 and at the end of the sampling period (week 54). The filter bag technique using an $\mathrm{ANKOM}^{200}$ Fiber Analyser (ANKOM Technology, Macedon, USA) with sodium sulphate and $\alpha$-amylase was used to measure neutral detergent fiber (NDF) and acid detergent fiber (ADF) (Van Soest et al. 1991), while acid detergent lignin (ADL) was determined by ashing the remaining fraction in beakers after NDF and ADF determinations (Van Soest 1963). Hemicellulose concentration was calculated as NDF minus ADF and cellulose concentration was calculated as ADF minus ADL, while ADL minus ash was assumed to be equivalent to the lignin concentration (Van Soest et al. 1991). Crude protein concentration was determined by multiplying the $\mathrm{N}$ concentrations from the Kjeldahl method by 6.25 (Kirk 1950). 


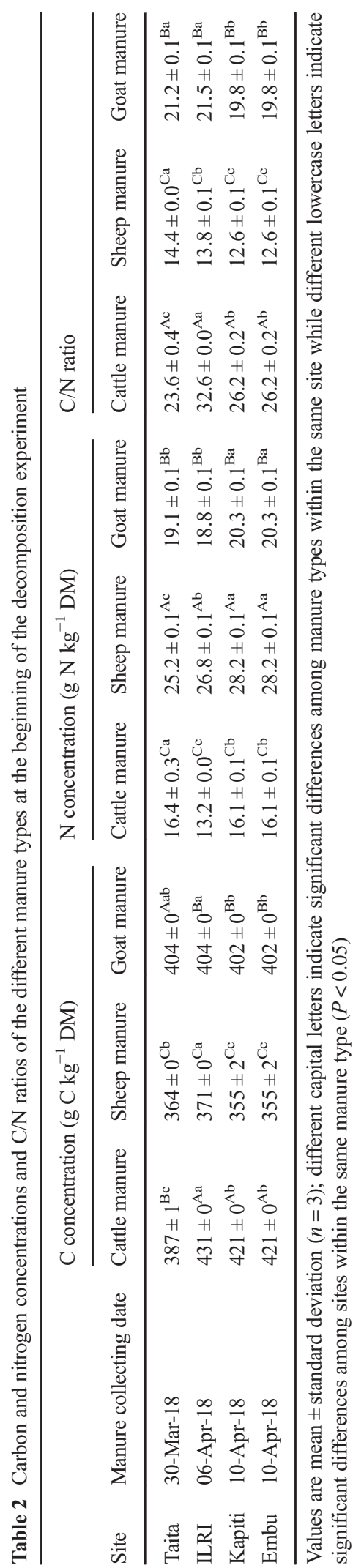

Calculation and data analysis

The decomposition rate $\left(k\right.$, year $\left.^{-1}\right)$ of manure was calculated using the following equation:

$k=\ln \left(M_{\mathrm{t}} / M_{0}\right)(-1 / t)$

where $M_{t}$ and $M_{0}$ are manure dry matter at time $\mathrm{t}$ and 0 (start), respectively; and $t$ is time in years. This equation was also used to calculate rates of $\mathrm{C}$ and $\mathrm{N}$ mineralization, where $M_{t}$ and $M_{0}$ are total manure $\mathrm{C}$ or $\mathrm{N}$ content at time $t$ and 0 , and $t$ is also time in years. These rates were only calculated for the samples collected at the end of the 378-day period.

Two-way ANOVA with Tukey's HSD posthoc test was used to test for differences of the various initial manure properties (e.g. C, N concentration and $\mathrm{C} / \mathrm{N}$ ratio) and for rates of manure decomposition and manure $\mathrm{C}$ and $\mathrm{N}$ mineralization, using manure types and sites as the two fixed factors. Differences in cellulose, hemicellulose, lignin and CP concentrations among sites and sampling dates within the same manure type were also tested using two-way ANOVA and Tukey's HSD test, with date and site as fixedfactors. Data were tested for homogeneity of variance using Levene's test, while residuals were tested for normality using the Shapiro-Wilk test, and variables were log-transformed if necessary. All statistical calculations were done with Aov package in R v3.6.1 ( $\mathrm{R}$ core team, 2019). The linear regression between decomposition rate and mean temperature, cumulative precipitation and aridity index (AI) was built with Sigmaplot 12.5 (Systat Software, Inc. SigmaPlot for Windows).

\section{Results}

Weather condition

Over the 378-day period, the Embu site had the highest mean temperature $\left(22.9^{\circ} \mathrm{C}\right)$ and the lowest cumulative precipitation $(209.3 \mathrm{~mm})$, while the lowest mean temperature $\left(18.0^{\circ} \mathrm{C}\right)$ and the highest cumulative precipitation $(1371.6 \mathrm{~mm})$ occurred at the ILRI site (Fig. 1b, d). Mean temperatures were within the range of the long-term records for all sites. However, cumulative precipitation at the Taita and Embu sites were 34\% and 50\% less than the longterm means (Ngetich et al. 2014; Pellikka et al. 
2018) (Fig. 1a, d), while the ILRI site had $58 \%$ more precipitation than the long-term mean (Pelster et al. 2016) (Fig. 1b). Precipitation at Kapiti during the observation period agreed well with long-term records (Table 1, Fig. 1c). The two warmer sites (Embu and Taita) received less cumulative precipitation during our observation period than the cooler sites (Kapiti and ILRI).

The aridity index was calculated as the ratio of precipitation to potential evapotranspiration based on the actual weather information during the observation period, with lower values indicating drier conditions (Wang

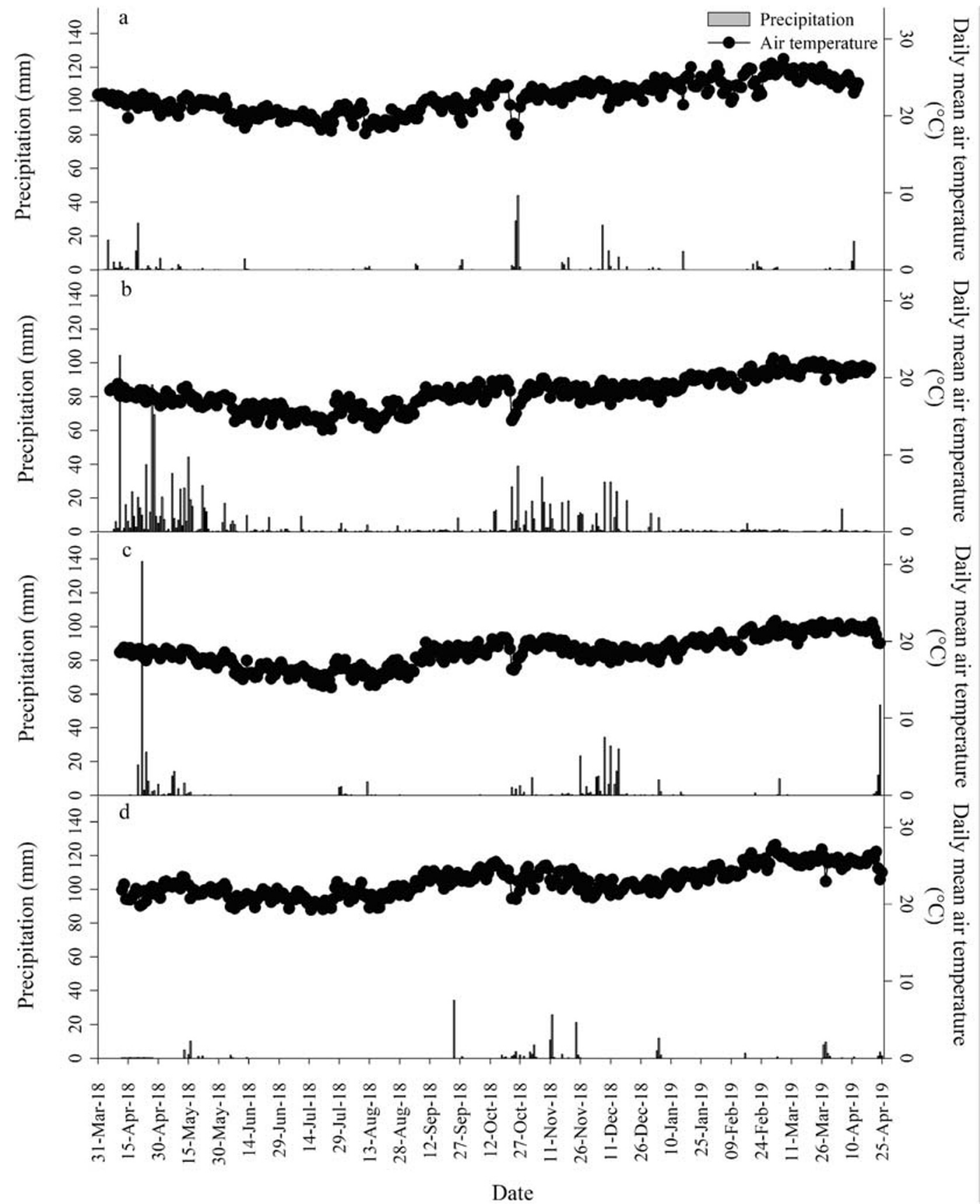

Fig. 1 The daily mean air temperature and precipitation at Taita site (a, from 31-Mar-18 to 13-Apr-19), ILRI site (b, from 06-Apr-18 to 19Apr-19), Kapiti site (c, from 11-Apr-18 to 24-Apr-19) and Embu site (d, from 12-Apr-18 to 25-Apr-19) 
et al. 2014). Both the Taita and Embu sites were defined as arid (i.e. aridity index of 0.18 and 0.12 for Taita and Embu sites, respectively). The Kapiti site was considered to be semi-arid $(\mathrm{AI}=0.37)$, while the ILRI site was humid $(\mathrm{AI}=0.92)$, due primarily to more precipitation (Table 1).

\section{Initial manure properties}

Due to different manure sampling dates, properties of cattle, sheep and goat manures slightly differed across sites (Table 2). Cattle manure used at the Taita site had the lowest $\mathrm{C}$ and highest $\mathrm{N}$ concentrations, while the cattle manure used at the ILRI site had the highest $\mathrm{C}$ and lowest $\mathrm{N}$ concentrations. Sheep manure also differed among sites, with sheep manure used at ILRI having slightly higher $\mathrm{C}$ concentrations than that at the other three sites, while sheep manure used at Kapiti and Embu had higher $\mathrm{N}$ concentrations. The $\mathrm{C}$ and $\mathrm{N}$ concentrations of goat manure used at the four sites were similar (Table 2). Sheep manure had lower $\mathrm{C}$ and higher $\mathrm{N}$ concentrations compared to cattle or goat manure at the same site, while cattle manure showed highest $\mathrm{C}$ and lowest $\mathrm{N}$ concentrations at all sites except Taita. The $\mathrm{C} / \mathrm{N}$ ratio ranged from 12.6 to 32.6 with sheep $<$ goats $<$ cattle manure (Table 2). Considering mineral $\mathrm{N}$ concen- trations in fresh manure, initial $\mathrm{NH}_{4}{ }^{+}$concentrations were highest in sheep manure at Taita, Kapiti and Embu $\left(2898 \pm 40,2871 \pm 48\right.$ and $2871 \pm 48 \mu \mathrm{g} \mathrm{N} \mathrm{g}{ }^{-1} \mathrm{DM}$, respectively), while at ILRI $\mathrm{NH}_{4}{ }^{+}$concentrations were highest in goat manure $\left(2764 \pm 37 \mu \mathrm{g} \mathrm{N} \mathrm{g}^{-1} \mathrm{DM}\right)$. For all manure types, initial $\mathrm{NO}_{3}{ }^{-}$concentration was negligible compared to $\mathrm{NH}_{4}{ }^{+}$concentration (Figs. 5, 6, 7).

Initial hemicellulose and cellulose concentrations were higher in cattle and goat manure than in sheep manure at all sites $(P<0.05$, Figs. $2,3,4)$. Initial cellulose concentrations showed the following order: cattle manure $>$ goat manure $>$ sheep manure, while initial CP concentrations showed the opposite order: sheep manure $>$ goat manure $>$ cattle manure. In contrast, initial lignin concentrations did not differ between the three manure types and the four sites (Figs. 2, 3, 4).

Temporal dynamics of manure components during the experimental period

After 378 days, approximately $70 \%$ of cattle manure and $50 \%$ of goat and sheep manure mass was lost. Temporal patterns of decomposition were similar regardless of manure type and sites. Dry matter decreased rapidly during the first several weeks,
Fig. 2 Cattle manure hemicellulose, cellulose, lignin and crude protein dynamics at Taita, ILRI, Kapiti and Embu sites. Each value represents the mean of two replicates for hemicellulose, cellulose and lignin and three replicates for crude protein ( \pm standard deviation); different capital letters indicate significant differences among sites within the same sampling date while lowercase letters indicate significant differences among sampling dates within the same site $(P<0.05)$

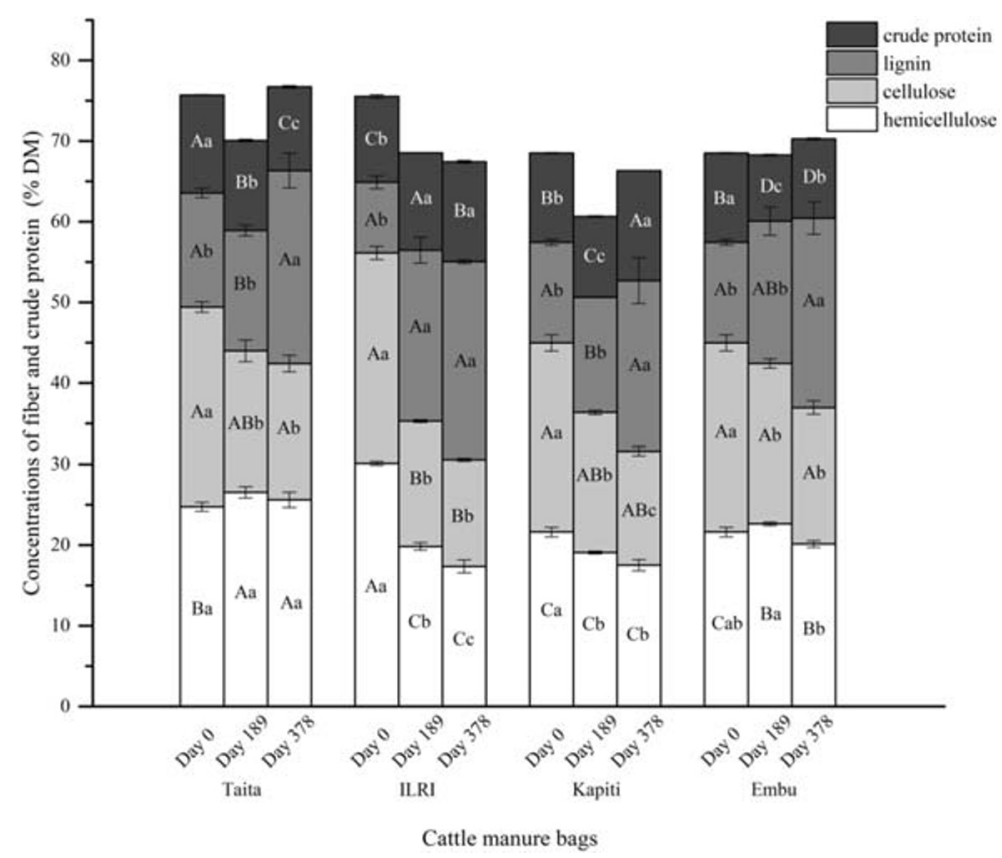


Fig. 3 Sheep manure

hemicellulose, cellulose, lignin and crude protein dynamics at Taita, ILRI, Kapiti and Embu sites. Each value represents the mean of two replicates for hemicellulose, cellulose and lignin and three replicates for crude protein $( \pm$ standard deviation); different capital letters indicate significant differences among sites within the same sampling date while different lowercase letters indicate significant differences among sampling dates within the same site $(P<0.05)$

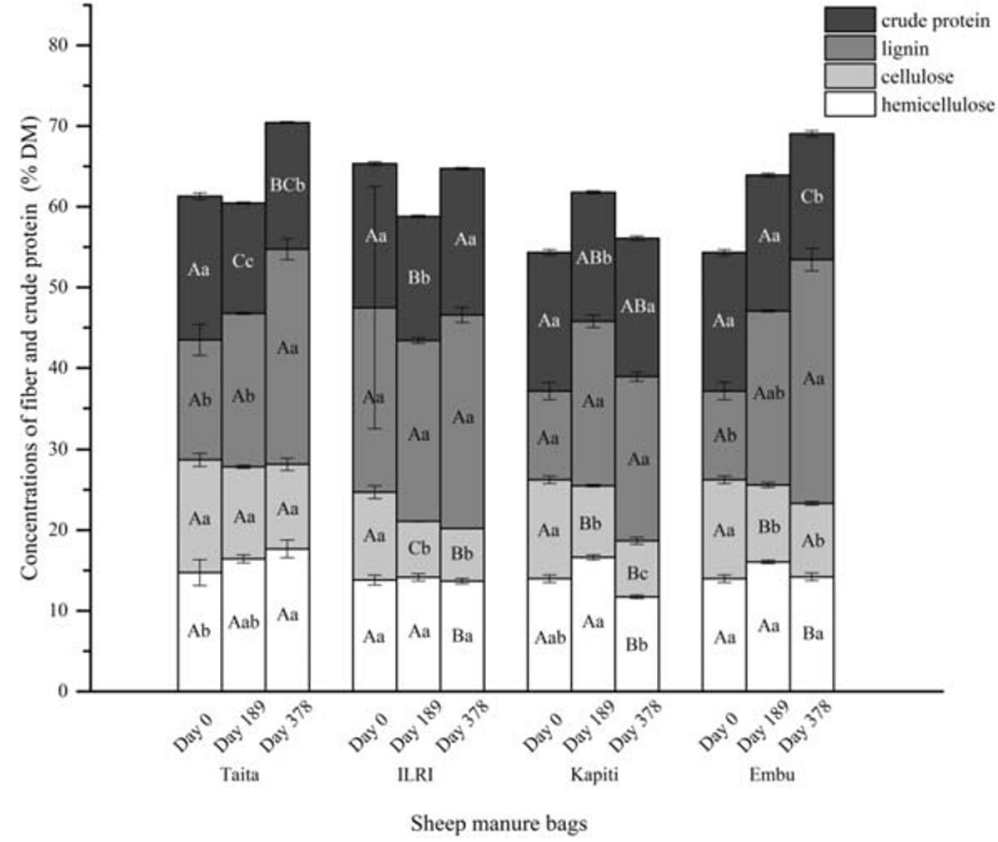

with the rate of DM decrease slowing down over time, except for cattle manure at Taita, where the initial loss was smaller compared to other sites (Figs. 5, 6, 7). Due to the manure DM loss, the absolute total $\mathrm{C}$ and $\mathrm{N}$ content also decreased rapidly in the first several weeks, although the $\mathrm{C}$ loss was faster than $\mathrm{N}$ loss. Consequently, $\mathrm{C} / \mathrm{N}$ ratios decreased over time (Figs. 5, 6, 7). Ammonium concentrations decreased exponentially during the first week after application, and remained low during the rest of the trial (Figs. 5, 6, 7), although short-term increases of manure $\mathrm{NH}_{4}{ }^{+}$concentrations were observed in conjunction with heavy rainfall events during the initial two months of the study. Crude protein concentrations remained rather constant throughout the 378 days sampling period,
Fig. 4 Goat manure

hemicellulose, cellulose, lignin and crude protein dynamics at Taita, ILRI, Kapiti and Embu sites. Each value represents the mean of two replicates for hemicellulose, cellulose and lignin and three replicates for crude protein $( \pm$ standard deviation); different capital letters indicate significant differences among sites within the same sampling date while different lowercase letters indicate significant differences among sampling dates within the same site $(P<0.05)$

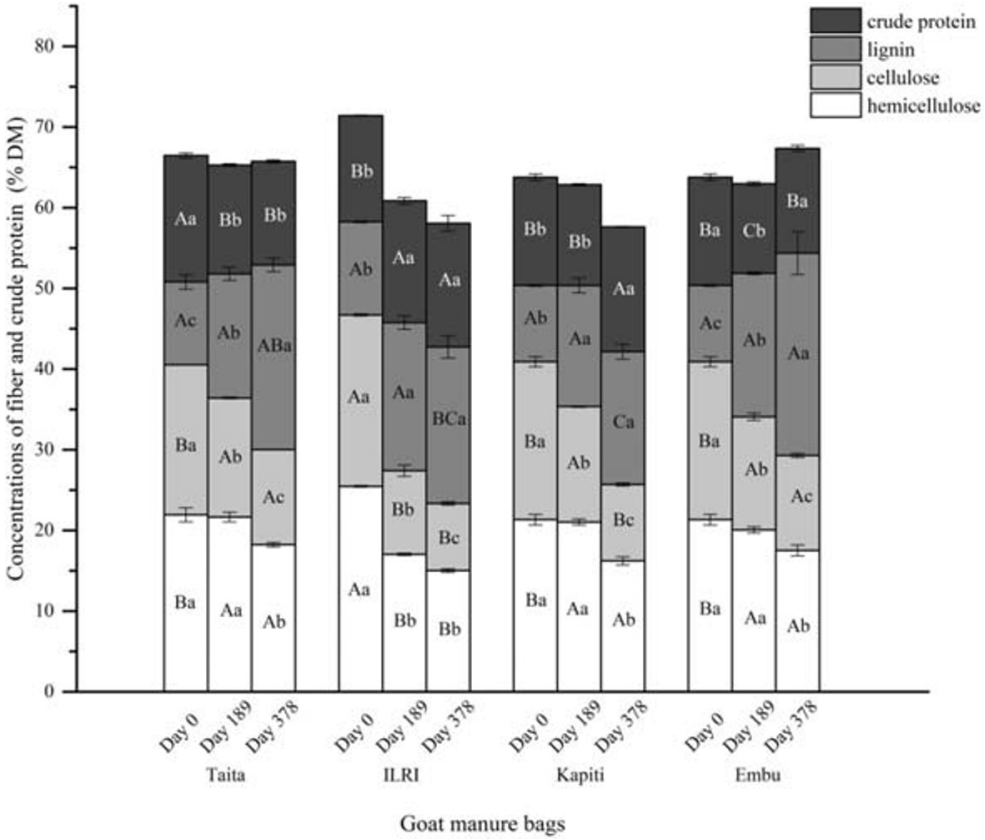




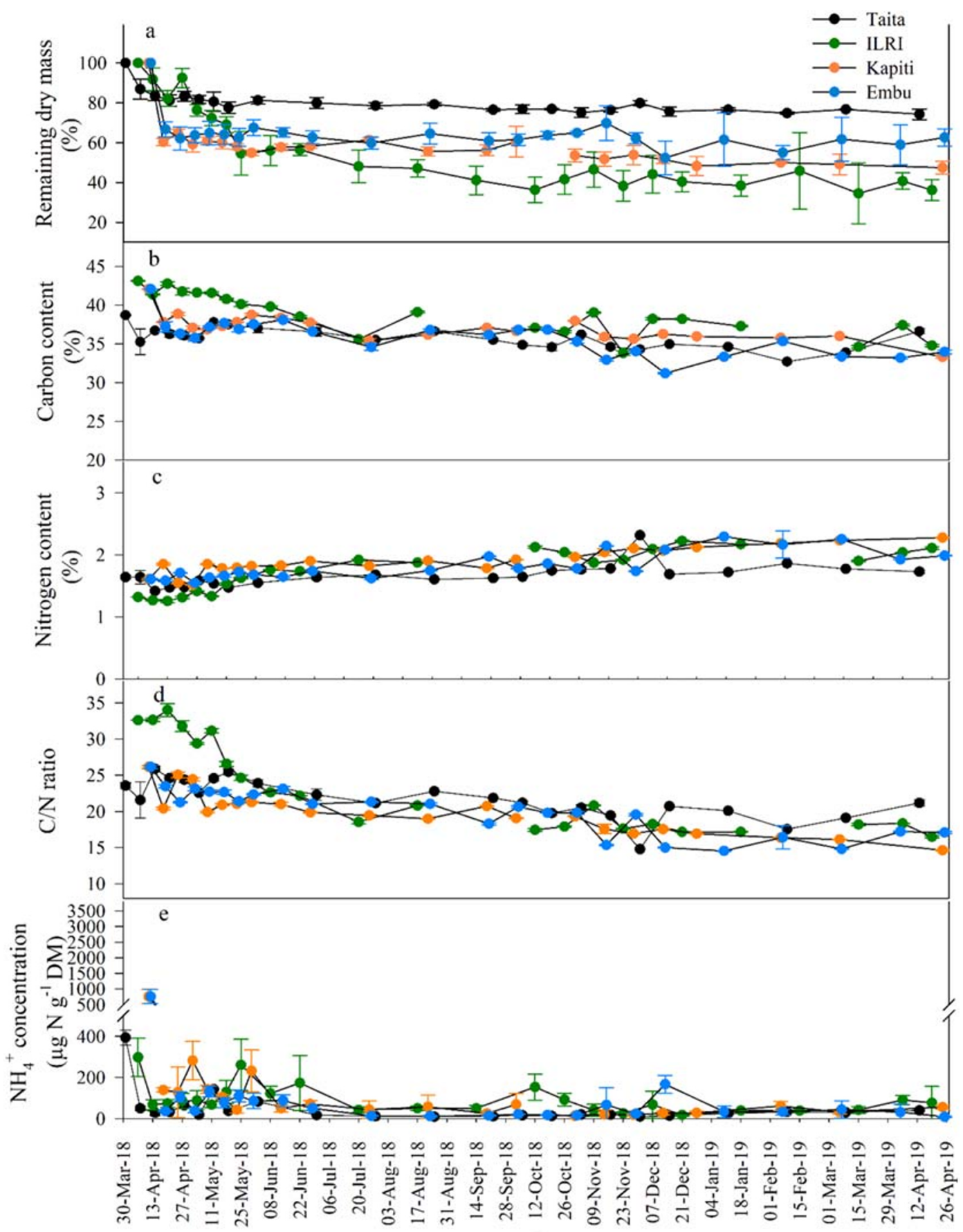

Date

Fig. 5 Dynamics of cattle manure remaining as dry mass (a), carbon concentration (b), nitrogen concentration (c), $\mathrm{C} / \mathrm{N}$ ratio (d) and $\mathrm{NH}_{4}{ }^{+}$concentration (e) after litter bags application at Taita,

while cellulose concentrations tended to decrease and lignin concentrations increased (Figs. 2, 3, 4). Hemicellulose concentrations in cattle and goat
ILRI, Kapiti and Embu sites, respectively. Each value represents the mean of three replicates ( \pm standard deviation). Note that at all sampling times manure $\mathrm{NO}_{3}{ }^{-}$concentrations were negligible

manure tended to decrease, with the exception of the cattle manure at Taita (Figs. 2 and 4). Unlike the other manure types, hemicellulose concentrations 


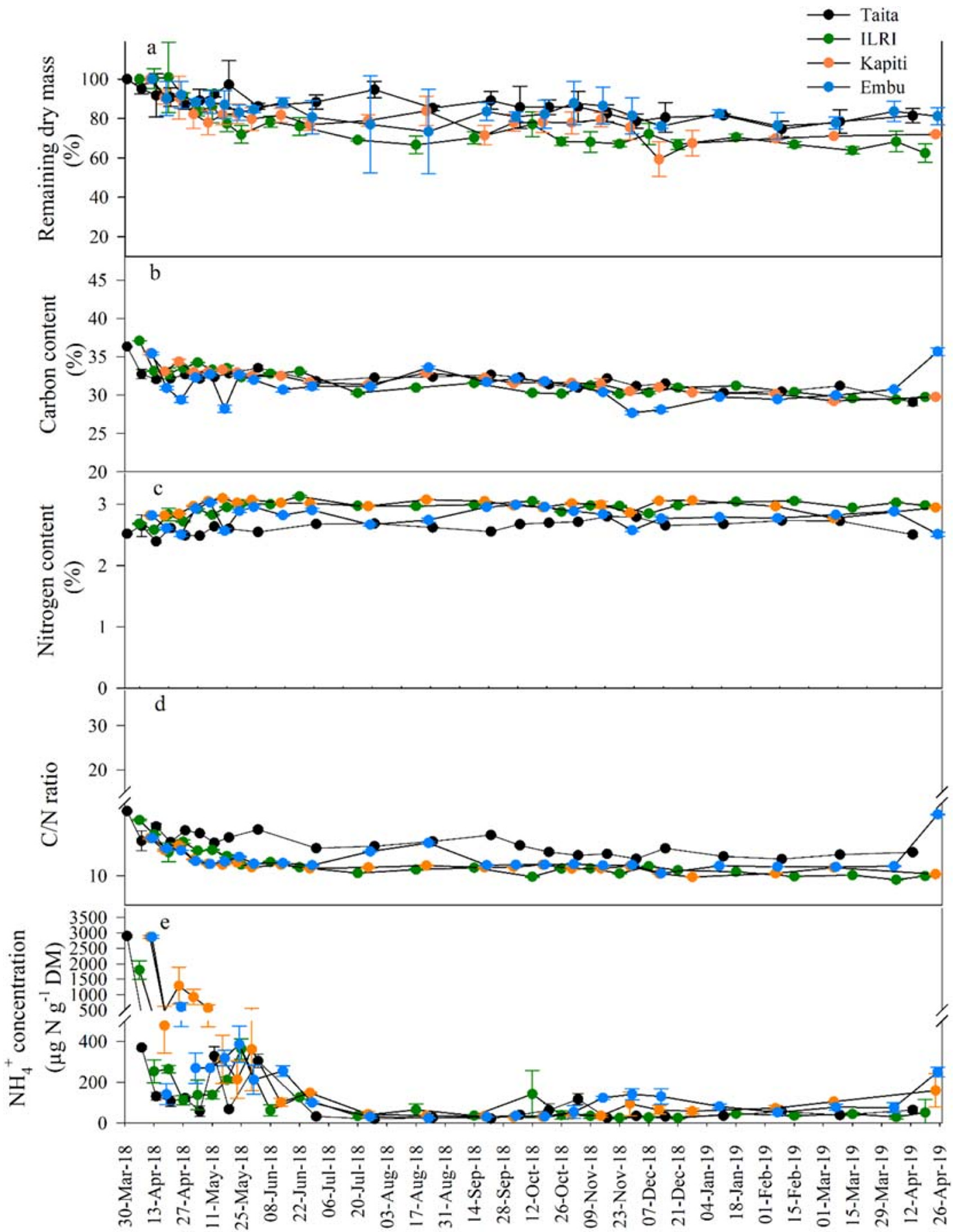

Date

Fig. 6 Dynamics of sheep manure remaining as dry mass (a), carbon concentration (b), nitrogen concentration (c), C/N ratio (d) and $\mathrm{NH}_{4}{ }^{+}$concentration (e) after litter bags application at Taita,

for sheep manure generally remained constant with the exception of Kapiti site, where hemicellulose
ILRI, Kapiti and Embu sites, respectively. Each value represents the mean of three replicates ( \pm standard deviation). Note that at all sampling times manure $\mathrm{NO}_{3}{ }^{-}$concentrations were negligible

concentrations were lower after 378 days as compared to initial values (Fig. 3). 


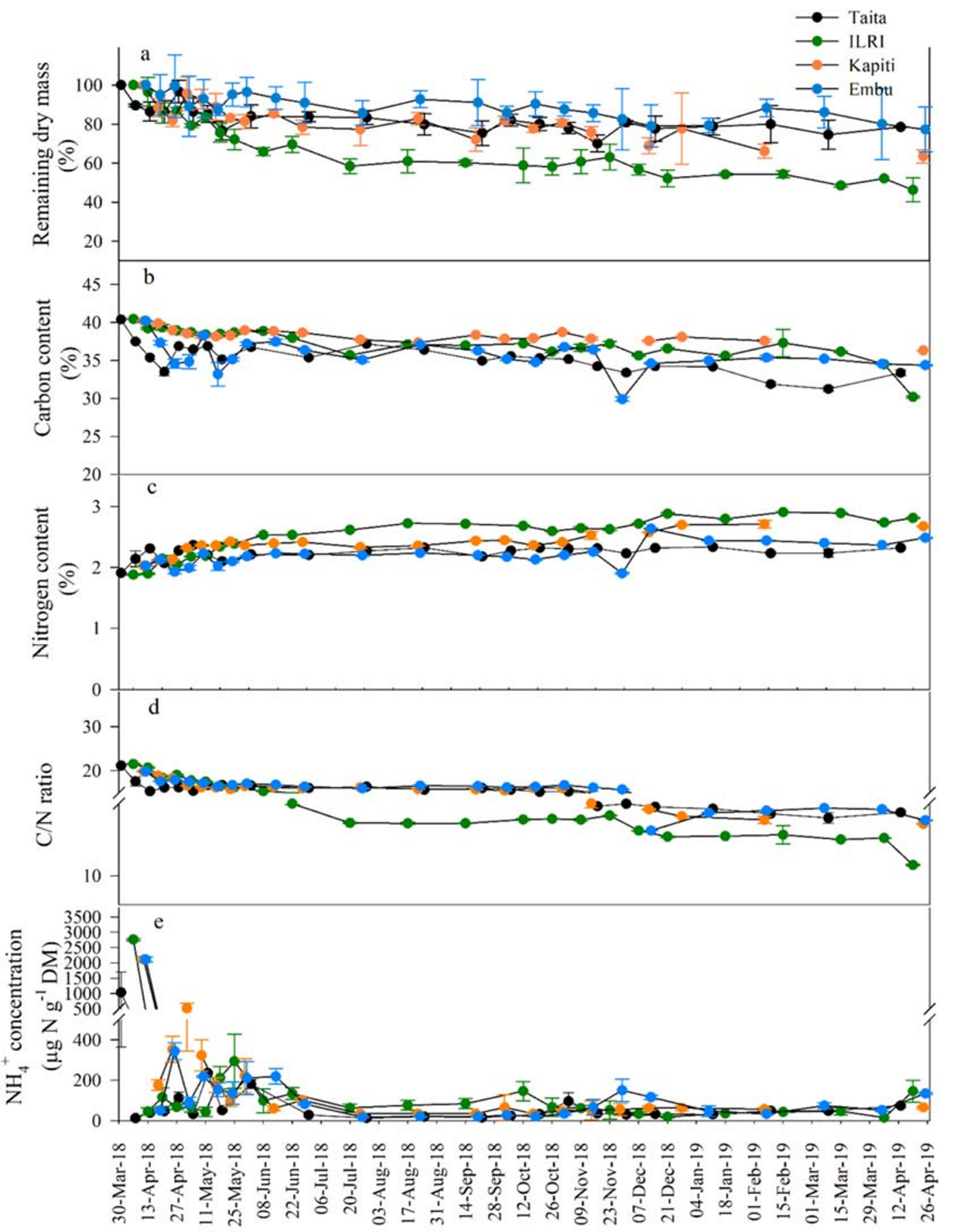

Date

Fig. 7 Dynamics of goat manure remaining as dry mass (a), carbon concentration (b), nitrogen concentration (c), $\mathrm{C} / \mathrm{N}$ ratio (d) and $\mathrm{NH}_{4}{ }^{+}$concentration (e) after litter bags application at Taita,
ILRI, Kapiti and Embu sites, respectively. Each value represents the mean of three replicates ( \pm standard deviation). Note that at all sampling times manure $\mathrm{NO}_{3}{ }^{-}$concentrations were negligible 


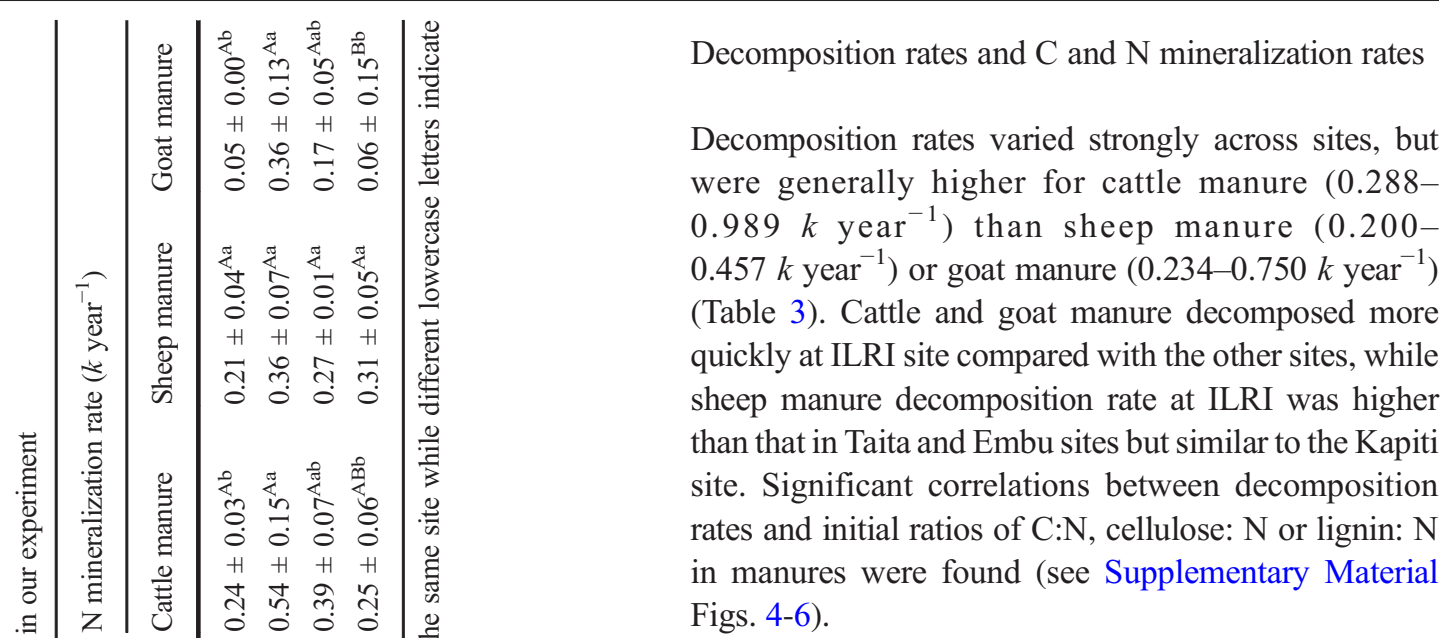

Between $4.6 \pm 0.2$ and $42.3 \pm 8.5 \%$ of manure $\mathrm{N}$ were lost over the entire observation period. The $\mathrm{N}$ mineralization rate was higher for cattle and goat manure at the ILRI site compared with that at Taita and Embu sites, whereas there was no difference in $\mathrm{N}$ mineralization rates among sites for sheep manure (Table 3). The $\mathrm{N}$ mineralization rates (ranging from 0.05 to $0.54 k$ year $^{-1}$ ) were similar among manure types at each site except for the Embu site, where the $\mathrm{N}$ mineralization rate from goat manure was lower than that of sheep manure (Table 3 ). The highest $\mathrm{C}$ mineralization rate $\left(1.20 \pm 0.15 k\right.$ year $\left.^{-1}\right)$ was observed for cattle manure at the ILRI site with $70.8 \pm$ $4.3 \%$ of $\mathrm{C}$ being mineralized. In contrast, sheep manure at the Embu site had the lowest $\mathrm{C}$ mineralization rate $\left(0.20 \pm 0.05 k\right.$ year $\left.^{-1}\right)$ with only $18.3 \pm 4.5 \%$ of the $\mathrm{C}$ being mineralized (Table 3 ). In general, $\mathrm{C}$ mineralization rates were higher at the ILRI site for all manure types, and cattle manure tended to have higher $\mathrm{C}$ mineralization rates than the other manure types at all sites.

The dry matter decomposition rate was positively correlated with cumulative precipitation (decomposition rate $=0.1969+0.0004 \times$ cumulative precipitation, $\left.n=35, \mathrm{R}^{2}=0.52, P<0.05\right)$ and negatively with mean air temperature (decomposition rate $=$ 2.081-0.080 × mean temperature, $\mathrm{n}=35, \mathrm{R}^{2}=0.47$, $P<0.05)$ regardless of the manure type. The aridity index, which considers both precipitation and air temperature to account for, showed a positive relation with dry matter decomposition rate (decomposition rate $=0.215+0.579 \times$ aridity index, $\mathrm{n}=35$, $\left.\mathrm{R}^{2}=0.53, P<0.05\right)$, indicating faster decomposition at more humid conditions (see Supplementary Material Figs. 1-3). 


\section{Discussion}

Livestock grazing is the most widespread form of herbivore management and significantly influences the vegetation of grasslands, which cover an area of 28-35 million $\mathrm{km}^{2}$ globally (Tanentzap and Coomes 2012). Grazing animals remove large amounts of plant biomass and translocate nutrients back to soil in the forms of urine and dung (Bakker et al. 2004; Güsewell et al. 2005). Consequently, decomposition of manure is crucial for returning nutrients to soils, and, thus, for maintaining overall ecosystem functioning. However, studies investigating the decomposition processes of manure deposited on pasture are scarce, especially in SSA. To our knowledge, globally only four field studies of manure decomposition in situ in grasslands are available, while a rather huge number of studies are available on manure decomposition rates under controlled laboratory conditions. Markewich et al. (2010) investigated the decomposition of manure differing in chemical composition after storage in small-scale Kenyan livestock systems with seven sampling times over 112 days and found that organic $\mathrm{N}$ in manure with higher concentrations of $\mathrm{N}$ disappeared more quickly than from manure with low initial N. Esse et al. (2001) measured cattle manure and sheep-goat manure decomposition with five sampling times over 17 weeks in south-west Niger and reported that manure decomposed faster on crusted than on sandy soil. Rashid et al. (2013) applied stacked or composted cattle manure to sandy and peat soils in the Netherlands with three sampling times over 240 days and found that the so-called "home-field advantage", which had been initially described for plant litter and suggests that litter decomposes faster in its home habitat (Ayres et al. 2009; Strickland et al. 2009), where microbial decomposer communities are adapted to the litter chemistry also had an effect on manure decomposition in grasslands. Somda and Powell (1998) used sheep manure from sheep fed on different diets to study decomposition dynamics in Kenya. On the basis of five sampling times over 112 days they showed that decomposition rates were affected by manure quality and seasonality. Given the paucity of data and the importance of excreta for $\mathrm{C}$ and $\mathrm{N}$ cycling of grassland ecosystems, it is obvious that more frequent samplings over longer time periods are necessary to better understand decomposition dynamics of manures, which are key for rangeland $\mathrm{C}$ and $\mathrm{N}$ cycling.
Influence of manure type on decomposition rate

Animal species may be an important source of variation in the decomposition rate of livestock manure as manure chemical composition differs due to the digestion capacity of different livestock species, even when fed on the same diet (Schlecht et al. 1997). Furthermore, different livestock species exhibit different feeding practices (i.e. grazers, browsers, intermediate feeders) (Searle and Shipley 2008). As an example, small ruminants actively select plants of higher nutritional value, which results in manure with higher $\mathrm{N}$ concentration compared to cattle manure (Shriver et al. 2003; ValdésCorrecher et al. 2019). The higher initial N concentration in sheep and goat manure in our study was consistent with previous studies, which also measured higher initial $\mathrm{N}$ concentrations in sheep/goat manure, and attributed that to selective feeding on $\mathrm{N}$-rich plants (Esse et al. 2001). However, in contrast to our expectations, and unlike previous studies that found negative correlations between litter decomposition rate and initial $\mathrm{C} / \mathrm{N}$ ratio (Bradford et al. 2016), manure decomposition rates in our study were higher for cattle manure than for sheep and goat manure despite the lower initial $\mathrm{N}$ concentration and higher $\mathrm{C} / \mathrm{N}$ ratio in cattle manure. However, our results are consistent with Chen et al. (2019) who reported that chicken manure, with high $\mathrm{N}$ concentrations and low $\mathrm{C} / \mathrm{N}$ ratio, decomposed more slowly than pig manure, highlighting the important role of manure chemical composition for decomposition. Previous studies have found that manure decomposition could be regulated by their main structural components such as cellulose (Morvan et al. 2006; Chen et al. 2019), as cellulose was found to be the primary substrate for glucan depolymerization at a later stage of decomposition after more labile $\mathrm{C}$ compounds such as sugars and starch had been depleted (Leitner et al. 2012). This regulation of the decomposition rate by cellulose could explain why cattle manure in the current study decomposed more quickly than the other manures even though it had a higher $\mathrm{C} / \mathrm{N}$ ratio. Starting concentrations of cellulose were around $25 \%$ in cattle manure, but $<20 \%$ in sheep and goat manures (Figs. 2, 3, 4). Cellulose in manure can decompose very fast because it is already rich in cellulolytic bacteria from the rumen (Liao et al. 2005). In addition, a large fraction of $\mathrm{N}$ was likely tied up in the cellulolignin complexes, indicating that the initial lignin and $\mathrm{N}$ ratio and also the ADF and ADL ratio played important roles in controlling 
decomposition rate in our study (see Supplementary Material, Figs. 6 and 7). Lignin compounds are very resistant to digestion by ruminants (Jung and Allen 1995), and they are known to provide physical protection to other $\mathrm{N}$-containing compounds such as cellwall proteins, which reduces their decomposability (Fioretto et al. 2005; de Bruijn and Butterbach-Bahl 2010). As lignin is more recalcitrant than other plant components (Morvan et al. 2006; Xu et al. 2017), even though it can have relatively high $\mathrm{N}$ contents, total $\mathrm{N}$ concentrations alone might be a poor predictor for decomposition.

Regardless of manure type, manure $\mathrm{NH}_{4}^{+}$concentrations diminished from 551, 2610, $2005 \mu \mathrm{g} \mathrm{N} \mathrm{g}^{-1} \mathrm{DM}$ for cattle manure, sheep manure and goat manure, respectively to values close to $100 \mu \mathrm{g} \mathrm{N} \mathrm{g}^{-1} \mathrm{DM}$ within one week after application. Only for cattle manure did the $\mathrm{NH}_{4}{ }^{+}$concentrations bounce back a few times during the initial two months of decomposition. This temporal dynamic in $\mathrm{NH}_{4}{ }^{+}$concentrations might be explained by the heavy rainfalls occurring during those times and the fact that the sheep and goat manure were much more compact as compared to the cattle manure. The lower density of the cattle manure made it easier to rewet, which likely increased cattle manure ammonification rates. Such a rapid change in manure $\mathrm{NH}_{4}{ }^{+}$ concentrations has also been reported by Markewich et al. (2010), suggesting that the high mineral $\mathrm{NH}_{4}{ }^{+}$ concentration in fresh manure, originating from the rapid decomposition of urea from urine, was either immobilized by the microbial decomposer community, volatilized as $\mathrm{NH}_{3}$, nitrified and leached or further denitrified and emitted as either $\mathrm{NO}, \mathrm{N}_{2} \mathrm{O}$ or $\mathrm{N}_{2}$ (Zhu et al. 2020).

In agreement with our third hypothesis, the $\mathrm{C} / \mathrm{N}$ ratio became narrower with increasing time of manure decomposition. This was also reported by Glaser et al. (2001) in a 120-day laboratory incubation experiment with cattle manure applied to savanna soils in Northern Tanzania. Comparable observations were also made by Sierra et al. (2013) in composted cattle manure. This shows while $\mathrm{C}$ is being mineralized and released as $\mathrm{CO}_{2}$, mineralized $\mathrm{N}$ is retained. Thereby, $\mathrm{N}$ immobilization seems to be associated with lignin, as lignin concentrations increased with decomposition time in our experiment (Figs. 2, 3, 4). According to the theory of ecological stoichiometry (Elser et al. 2003; Zechmeister-Boltenstern et al. 2015), microbial decomposers can only build their biomass when they have access to both $\mathrm{C}$ and $\mathrm{N}$ in a rather narrow ratio (3-10).
However, when the substrate that they are growing on has a very wide $\mathrm{C} / \mathrm{N}(>25)$, they have to import $\mathrm{N}$ from soil into the litter/manure (for example via hyphal networks) leading to net $\mathrm{N}$ immobilization in the decomposing substrate (Osono and Takeda 2004; Pei et al. 2019).

The manure decomposition rates in our study $(0.200$ to $0.989 k$ year $^{-1}$ ) (Table 3) are comparable to those found by Chen et al. (2019) for pig manure $\left(0.516 k\right.$ year $\left.^{-1}\right)$ and chicken manure $\left(0.483 k\right.$ year $\left.^{-1}\right)$ applied to cropland. However, our measured rates are generally lower than a previous study in Western Kenya that measure decomposition rates ranging from 0.907 and $1.214 \mathrm{kyear}^{-1}$ (Markewich et al. 2010). In addition, $23-74 \%$ of the DM had disappeared from the cattle manure bags after 378 days in our study, which is similar to the $39-80 \%$ of the DM lost from solid cattle manure bags in a study carried out in the Netherlands (Rashid et al. 2013). However, only $31-42 \%$ of $\mathrm{N}$ was lost in the current study, less than the 56-98\% N loss found by Rashid et al. (2013). This difference in $\mathrm{N}$ loss rates might be explained by the higher initial manure $\mathrm{N}$ concentration and lower $\mathrm{C} / \mathrm{N}$ ratio in the latter study, as higher initial $\mathrm{N}$ concentrations can favor $\mathrm{N}$ mineralization (Kuypers et al. 2018), but also N loss. Furthermore, the litterbags used by Rashid et al. (2013) had a larger mesh size $(4 \mathrm{~mm})$ than our study $(1 \mathrm{~mm})$, through which herbivorous soil fauna can access the manure, which might increase DM as well as $\mathrm{N}$ loss.

\section{Climate effect on decomposition rate}

In our study, the decomposition rate was positively correlated with cumulative precipitation, but negatively correlated with mean temperature. Many studies have reported positive effects of warming on litter decomposition (Lu et al. 2013; Yue et al. 2015). This is because warming stimulates microbial activity and accelerates enzyme kinetics (Conant et al. 2011), which are closely linked to decomposition rates (Allison et al. 2013). However, the current study was conducted in the tropics where temperature is not per se limiting. Furthermore, the warmer sites received less precipitation and experienced high vapor pressure deficits that caused rapid water loss and crust formation, likely slowing down microbial decomposition of the manure (Zhu et al. 2018). This is consistent with Prieto et al. (2019) who also found a negative effect of warming and reduced rainfall on litter decomposition in a semi-arid shrubland 
because of the desiccating effect of warming and decreased water input. In line with this we found a positive correlation between aridity index and decomposition rate, indicating that decomposition was faster in moister locations. The importance of water availability for litter decomposition has been highlighted by many previous studies (e.g. Wardle et al. 2004; García-Palacios et al. 2016b; Almagro et al. 2017), as rainfall is required to keep manure and soils wet, which in turn stimulates microbial activity and enzyme diffusion, which ultimately drives the decomposition process (Jacobson et al. 2015; Gliksman et al. 2017). Besides, rainfall may also have accelerated nutrient leaching from the litter bags, which likely also contributed to manure mass loss (Wang et al. 2009). The amount of manure in the litter bags however was much smaller than what a goat, sheep or cow would normally deposit on a grassland, resulting in a larger surface area to volume ratio in the litter bags compared to normal conditions. This larger ratio could influence how climate, in particular the amount and severity of drying and rewetting, effects manure decomposition. Unfortunately, this issue with scaling remains unstudied to our knowledge.

Similar to our study, Esse et al. (2001) studied the decomposition of sheep-goat and cattle manure in an 18-week field incubation in West Africa and reported that more than half of manure mass remained at the end of the trial, and that over time, $\mathrm{N}$ concentrations increased relatively to $\mathrm{C}$ concentrations. These authors argued that the observed rather low manure decomposition rates were caused by very high temperature $\left(30^{\circ} \mathrm{C}\right)$ and low precipitation $(350 \mathrm{~mm})$, which in their case accelerated crust formation and slowed down the decomposition process.

Uncertainty of decomposition rate estimates due to exclusion of soil fauna

Soil macrofauna and mesofauna (e.g. termites, beetles, nematodes) are able to fragment and shred litter material with their mouthparts, altering litter structure and facilitating microbial access, thus accelerating litter decomposition (Wang et al. 2010). By excluding soil macrofauna in our study, we therefore likely underestimated manure decomposition rates. Indeed, a previous study in Niger, West Africa by Esse et al. (2001) reported that manure in cages with mesofauna decomposed faster than manure in litter bags where meso- and macrofauna were excluded. In addition, a global decomposition experiment by Wall et al. (2008) also demonstrated that soil meso- and macrofauna increased litter decomposition rates in temperate and wet tropical climates. Termites and ants are widespread in the soil in Kenya (Markewich et al. 2010), and previous studies have reported termites appearing rapidly after dung deposition on rangelands in SSA (Pelster et al. 2016; Zhu et al. 2018). Through using the fibrous manure material in their mounds, a significant portion of manure applied may be degraded and/or translocated by the soil fauna (Diamond 1998; Markewich et al. 2010). Besides, application of cattle manure to grassland was shown to increase soil faunal abundance and activity (Forge et al. 2005; Stark et al. 2008), which in turn can increase manure decomposition rates. Therefore, due to exclusion of interactions with the soil fauna, readers should be aware that the reported decomposition rates in our study are likely at the lower end of manure decomposition under unrestricted conditions.

\section{Conclusion}

In this study, we found that manure decomposition rates ranged from 0.200 to $0.989 k$ year $^{-1}$ and were both influenced by manure chemical composition and climatic conditions. Manure chemical composition (i.e. cellulose and lignin concentration) was a better predictor of manure decomposition rates than manure total $\mathrm{N}$ and $\mathrm{C} / \mathrm{N}$ ratio. Furthermore, as air temperature at our tropical study sites was not limiting, precipitation was the main environmental driving factor for manure decomposition, which was also reflected by the strong correlation between decomposition and aridity index (i.e. higher AI indicating moister conditions was leading to faster decomposition). Surprisingly, a large proportion of manure $(30 \%$ for cattle, $50 \%$ for sheep and goats) mass remained after the 378 days field experiment. To enhance our understanding of $\mathrm{C}$ and $\mathrm{N}$ dynamics in manure decomposition in tropical regions, longterm studies that cover the whole decomposition period are needed. In addition, the role of soil macrofauna on manure decomposition in tropical grassland also needs further investigation as especially termites are known to be keystone species in many savanna ecosystems, but their impact on manure decomposition and ecosystem $\mathrm{C}$ and $\mathrm{N}$ cycling is still poorly understood. 
Acknowledgements The authors would like to thank Katrin Schneider for aridity index calculation, Mwadime Mjomba of the Taita Research Station of the University of Helsinki and also the continuous help from the Mazingira Centre team. Yuhao Zhu acknowledges financial support from the China Scholarship Council (201506350087). Major funding was provided by the Research Program ATMO within the Earth and Environment Program of the German Helmholtz Association, by the German Federal Ministry for Economic Cooperation and Development (BMZ), and the German Technical Cooperation (GIZ) under the project "In situ assessment of GHG emissions from two livestock systems in East Africa- determining current status and quantifying mitigation options" as well as under the International Fund for Agricultural Development (IFAD) funds project "Greening livestock: Incentive-based interventions for reducing the climate impact of livestock in East Africa". Lutz Merbold, David Pelster, Sheila Abwanda Okoma, Alice Anyango Onyango and Sonja Leitner further acknowledge the support received for CGIAR Fund Council, Australia (ACIAR), Irish Aid, the European Union, the Netherlands, New Zealand, Switzerland, UK, USAID and Thailand for funding to the CGIAR Research Program on Climate Change, Agriculture and Food Security (CCAFS) as well as for the CGIAR Research Program on Livestock. Petri Pellikka acknowledge Academy of Finland project: SMARTLAND - Environmental sensing of ecosystem services for developing climate smart landscape framework to improve food security in East Africa, decision number 318645. We acknowledge the TAHMO weather network and Matti Barthel at ETH Zurich for providing the weather information for Embu.

Funding Information Open Access funding provided by Projekt DEAL.

Open Access This article is licensed under a Creative Commons Attribution 4.0 International License, which permits use, sharing, adaptation, distribution and reproduction in any medium or format, as long as you give appropriate credit to the original author(s) and the source, provide a link to the Creative Commons licence, and indicate if changes were made. The images or other third party material in this article are included in the article's Creative Commons licence, unless indicated otherwise in a credit line to the material. If material is not included in the article's Creative Commons licence and your intended use is not permitted by statutory regulation or exceeds the permitted use, you will need to obtain permission directly from the copyright holder. To view a copy of this licence, visit http://creativecommons.org/licenses/by/4.0/.

\section{References}

Aerts R (1997) Climate, leaf litter chemistry and leaf litter decomposition in terrestrial ecosystems: a triangular relationship. Oikos 79:439. https://doi.org/10.2307/3546886

Allison SD, Lu Y, Weihe C, Goulden ML, Martiny AC, Treseder KK, Martiny JBH (2013) Microbial abundance and composition influence litter decomposition response to environmental change. Ecology 94:714-725. https://doi.org/10.1890/121243.1
ASCE-EWRI (2004) The ASCE standardized reference evapotranspiration equation. Technical committee report to the environmental and water resources Institute of the American Society of civil engineers from the task committee on standardization of reference evapotranspiration. American Society of Civil Engineers, Reston

Ayres E, Steltzer H, Simmons BL, Simpson RT, Steinweg JM, Wallenstein MD, Mellor N, Parton WJ, Moore JC, Wall DH (2009) Home-field advantage accelerates leaf litter decomposition in forests. Soil Biol Biochem 41:606-610. https://doi.org/10.1016/j.soilbio.2008.12.022

Bakker ES, Olff H, Boekhoff M, Gleichman JM, Berendse F (2004) Impact of herbivores on nitrogen cycling: contrasting effects of small and large species. Oecologia 138:91-101. https://doi.org/10.1007/s00442-003-1402-5

Banegas N, Albanesi AS, Pedraza RO, Dos Santos DA (2015) Non-linear dynamics of litter decomposition under different grazing management regimes. Plant Soil 393:47-56. https://doi.org/10.1007/s11104-015-2472-y

Bradford MA, Berg B, Maynard DS, Wieder WR, Wood SA (2016) Understanding the dominant controls on litter decomposition. J Ecol 104:229-238. https://doi.org/10.1111/13652745.12507

Brümmer C, Brüggemann N, Butterbach-Bahl K, Falk U, Szarzynski J, Vielhauer K, Wassmann R, Papen H (2008) Soil-atmosphere exchange of $\mathrm{N}_{2} \mathrm{O}$ and $\mathrm{NO}$ in near-natural savanna and agricultural land in Burkina Faso (W. Africa). Ecosystems 11:582-600. https://doi.org/10.1007/s10021008-9144-1

Chapin FS, Matson PA, Vitousek PM (2011) Principles of terrestrial ecosystem ecology. Springer Science \& Business Media, New York

Chen Z, Xu Y, Cusack DF, Castellano MJ, Ding W (2019) Molecular insights into the inhibitory effect of nitrogen fertilization on manure decomposition. Geoderma 353:104115. https://doi.org/10.1016/j.geoderma.2019.06.034

Conant RT, Ryan MG, Ågren GI, Birge HE, Davidson EA, Eliasson PE, Evans SE, Frey SD, Giardina CP, Hopkins FM, Hyvönen R, Kirschbaum MUF, Lavallee JM, Leifeld J, Parton WJ, Megan Steinweg J, Wallenstein MD, Martin Wetterstedt JÅ, Bradford MA (2011) Temperature and soil organic matter decomposition rates - synthesis of current knowledge and a way forward. Glob Chang Biol 17:33923404. https://doi.org/10.1111/j.1365-2486.2011.02496.x

Coûteaux M-M, Bottner P, Berg B (1995) Litter decomposition, climate and litter quality. Trends Ecol Evol 10:63-66. https://doi.org/10.1016/S0169-5347(00)88978-8

de Bruijn AMG, Butterbach-Bahl K (2010) Linking carbon and nitrogen mineralization with microbial responses to substrate availability - the DECONIT model. Plant Soil 328:271-290. https://doi.org/10.1007/s11104-009-0108-9

Diamond J (1998) Ants, crops, and history. Science 281(80): 1974-1975

Elser JJ, Acharya K, Kyle M, Cotner J, Makino W, Markow T, Watts T, Hobbie S, Fagan W, Schade J, Hood J, Sterner RW (2003) Growth rate-stoichiometry couplings in diverse biota. Ecol Lett 6:936-943. https://doi.org/10.1046/j.14610248.2003.00518.x

Esse PC, Buerkert A, Hiernaux P, Assa A (2001) Decomposition of and nutrient release from ruminant manure on acid sandy soils in the Sahelian zone of Niger, West Africa. Agric 
Ecosyst Environ 83:55-63. https://doi.org/10.1016/S01678809(00)00264-4

FAO (2009) The state of food and agriculture. Livestock in balance. Food and Agriculture Organization of the United Nations, Rome

Fioretto A, Di Nardo C, Papa S, Fuggi A (2005) Lignin and cellulose degradation and nitrogen dynamics during decomposition of three leaf litter species in a Mediterranean ecosystem. Soil Biol Biochem 37:1083-1091. https://doi. org/10.1016/j.soilbio.2004.11.007

Forge TA, Bittman S, Kowalenko CG (2005) Responses of grassland soil nematodes and protozoa to multi-year and singleyear applications of dairy manure slurry and fertilizer. Soil Biol Biochem 37:1751-1762. https://doi.org/10.1016/j. soilbio.2004.11.013

García-Palacios P, Prieto I, Ourcival JM, Hättenschwiler S (2016a) Disentangling the litter quality and soil microbial contribution to leaf and fine root litter decomposition responses to reduced rainfall. Ecosystems 19:490-503. https://doi. org/10.1007/s10021-015-9946-X

García-Palacios P, Shaw EA, Wall DH, Hättenschwiler S (2016b) Temporal dynamics of biotic and abiotic drivers of litter decomposition. Ecol Lett 19:554-563. https://doi. org/10.1111/ele. 12590

Glaser B, Lehmann J, Führböter M, Solomon D, Zech W (2001) Carbon and nitrogen mineralization in cultivated and natural savanna soils of northern Tanzania. Biol Fertil Soils 33:301309. https://doi.org/10.1007/s003740000324

Gliksman D, Rey A, Seligmann R, Dumbur R, Sperling O, Navon Y, Haenel S, de Angelis P, Arnone JA III, Grünzweig JM (2017) Biotic degradation at night, abiotic degradation at day: positive feedbacks on litter decomposition in drylands. Glob Chang Biol 23:1564-1574. https://doi.org/10.1111 /gcb.13465

Güsewell S, Jewell PL, Edwards PJ (2005) Effects of heterogeneous habitat use by cattle on nutrient availability and litter decomposition in soils of an alpine pasture. Plant Soil 268: 135-149. https://doi.org/10.1007/s11104-004-0304-6

Handa IT, Aerts R, Berendse F, Berg MP, Bruder A, Butenschoen O, Chauvet E, Gessner MO, Jabiol J, Makkonen M, McKie BG, Malmqvist B, Peeters ETHM, Scheu S, Schmid B, van Ruijven J, Vos VCA, Hättenschwiler S (2014) Consequences of biodiversity loss for litter decomposition across biomes. Nature 509:218-221. https://doi.org/10.1038/nature13247

Haynes RJ, Williams PH (1993) Nutrient cycling and soil fertility in the grazed pasture ecosystem. Adv Agron 49:119-199. https://doi.org/10.1016/S0065-2113(08)60794-4

Heim A, Frey B (2004) Early stage litter decomposition rates for swiss forests. Biogeochemistry 70:299-313. https://doi. org/10.1007/s10533-003-0844-5

Hishinuma T, Ichi AJ, Osono T, Takeda H (2017) Litter quality control of decomposition of leaves, twigs, and sapwood by the white-rot fungus Trametes versicolor. Eur J Soil Biol 80: 1-8. https://doi.org/10.1016/j.ejsobi.2017.03.002

Hood-Nowotny R, Hinko-Najera Umana N, Inselbacher E et al (2010) Alternative methods for measuring inorganic, organic, and total dissolved nitrogen in soil. Soil Sci Soc Am J 74: 1018-1027. https://doi.org/10.2136/sssaj2009.0389

Houghton RA (2007) Balancing the global carbon budget. Annu Rev Earth Planet Sci 35:313-347. https://doi.org/10.1146 /annurev.earth.35.031306.140057
Hufkens K, Keenan TF, Flanagan LB, Scott RL, Bernacchi CJ, Joo E, Brunsell NA, Verfaillie J, Richardson AD (2016) Productivity of north American grasslands is increased under future climate scenarios despite rising aridity. Nat Clim Chang 6:710-714. https://doi.org/10.1038/nclimate2942

Jacobson K, Van Diepeningen A, Evans S et al (2015) Non-rainfall moisture activates fungal decomposition of surface litter in the Namib Sand Sea. PLoS One 10. https://doi.org/10.1371 /journal.pone.0126977

Jung HG, Allen MS (1995) Characteristics of plant cell walls affecting intake and digestibility of forages by ruminants. J Anim Sci 73:2774-2790. https://doi.org/10.2527 /1995.7392774x

Kirk PL (1950) Kjeldahl method for total nitrogen. Anal Chem 22: 354-358. https://doi.org/10.1021/ac60038a038

Knops JMH, Bradley KL, Wedin DA (2002) Mechanisms of plant species impacts on ecosystem nitrogen cycling. Ecol Lett 5: 454 466. https://doi.org/10.1046/j.1461-0248.2002.00332.x

Kuypers MMM, Marchant HK, Kartal B (2018) The microbial nitrogen-cycling network. Nat Rev Microbiol 16:263-276

Leitner S, Wanek W, Wild B, Haemmerle I, Kohl L, Keiblinger KM, Zechmeister-Boltenstern S, Richter A (2012) Influence of litter chemistry and stoichiometry on glucan depolymerization during decomposition of beech (Fagus sylvatica L.) litter. Soil Biol Biochem 50:174-187. https://doi.org/10.1016 j.soilbio.2012.03.012

Liao W, Wen Z, Hurley S, Liu Y, Liu C, Chen S (2005) Effects of hemicellulose and lignin on enzymatic hydrolysis of cellulose from dairy manure. Appl Biochem Biotechnol - Part A Enzym Eng Biotechnol 124:1017-1030. https://doi. org/10.1385/ABAB:124:1-3:1017

Lu M, Zhou X, Yang Q, Li H, Luo Y, Fang C, Chen J, Yang X, Li B (2013) Responses of ecosystem carbon cycle to experimental warming: a meta-analysis. Ecology 94:726-738. https://doi.org/10.1890/12-0279.1

Markewich HA, Pell AN, Mbugua DM, Cherney DJR, van Es HM, Lehmann J, Robertson JB (2010) Effects of storage methods on chemical composition of manure and manure decomposition in soil in small-scale Kenyan systems. Agric Ecosyst Environ 139:134-141. https://doi.org/10.1016/j. agee.2010.07.010

Matulich KL, Martiny JBH (2015) Microbial composition alters the response of litter decomposition to environmental change. Ecology 96:154-163. https://doi.org/10.1890/140357.1

Moir JL, Cameron KC, Di HJ, Fertsak U (2011) The spatial coverage of dairy cattle urine patches in an intensively grazed pasture system. J Agric Sci 149:473-485. https://doi. org/10.1017/S0021859610001012

Morvan T, Nicolardot B, Péan L (2006) Biochemical composition and kinetics of $\mathrm{C}$ and $\mathrm{N}$ mineralization of animal wastes: a typological approach. Biol Fertil Soils 42:513-522. https://doi.org/10.1007/s00374-005-0045-6

Ngetich KF, Diels J, Shisanya CA, Mugwe JN, Mucheru-muna M, Mugendi DN (2014) Effects of selected soil and water conservation techniques on runoff, sediment yield and maize productivity under sub-humid and semi-arid conditions in Kenya. Catena 121:288-296. https://doi.org/10.1016/j. catena.2014.05.026

Oenema O, Wrage N, Velthof GL, van Groenigen JW, Dolfing J, Kuikman PJ (2005) Trends in global nitrous oxide emissions 
from animal production systems. Nutr Cycl Agroecosystems 72:51-65. https://doi.org/10.1007/s10705-004-7354-2

Osono T, Takeda H (2004) Accumulation and release of nitrogen and phosphorus in relation to lignin decomposition in leaf litter of 14 tree species. Ecol Res 19:593-602. https://doi. org/10.1111/j.1440-1703.2004.00675.x

Parton W, Silver WL, Burke IC et al (2007) Global-scale similarities in nitrogen release patterns during long-term decomposition. Science (80- ) 315:361-364. https://doi.org/10.1126 /science.1134853

Pei G, Liu J, Peng B, Gao D, Wang C, Dai W, Jiang P, Bai E (2019) Nitrogen, lignin, $\mathrm{C} / \mathrm{N}$ as important regulators of gross nitrogen release and immobilization during litter decomposition in a temperate forest ecosystem. For Ecol Manag 440:61-69. https://doi.org/10.1016/j.foreco.2019.03.001

Pellikka PKE, Heikinheimo V, Hietanen J, Schäfer E, Siljander M, Heiskanen J (2018) Impact of land cover change on aboveground carbon stocks in Afromontane landscape in Kenya. Appl Geogr 94:178-189. https://doi.org/10.1016/j. apgeog.2018.03.017

Pelster DE, Gisore B, Goopy J, Korir D, Koske JK, Rufino MC, Butterbach-Bahl K (2016) Methane and nitrous oxide emissions from cattle excreta on an east African grassland. J Environ Qual 45:1531-1539. https://doi.org/10.2134 /jeq2016.02.0050

Powell JM, Fernández-Rivera S, Hiernaux P, Turner MD (1996) Nutrient cycling in integrated rangeland/cropland systems of the Sahel. Agric Syst 52:143-170. https://doi.org/10.1016 /0308-521X(96)00009-1

Prieto I, Almagro M, Bastida F, Querejeta JI (2019) Altered leaf litter quality exacerbates the negative impact of climate change on decomposition. J Ecol 107:2364-2382. https://doi.org/10.1111/1365-2745.13168

Rashid MI, de Goede RGM, Brussaard L, Lantinga EA (2013) Home field advantage of cattle manure decomposition affects the apparent nitrogen recovery in production grasslands. Soil Biol Biochem 57:320-326. https://doi.org/10.1016/j. soilbio.2012.10.005

Rufino MC, Rowe EC, Delve RJ, Giller KE (2006) Nitrogen cycling efficiencies through resource-poor African croplivestock systems. Agric Ecosyst Environ 112:261-282. https://doi.org/10.1016/j.agee.2005.08.028

Salvati L, Carlucci M (2015) Towards sustainability in agro-forest systems? Grazing intensity, soil degradation and the socioeconomic profile of rural communities in Italy. Ecol Econ 112:1-13. https://doi.org/10.1016/j.ecolecon.2015.02.001

Schlecht E, Fernández-Rivera S, Hiernaux P (1997) Timing, size and $\mathrm{N}$-concentration of faecal and urinary excretions in cattle, sheep and goats - can they be used for better manuring of cropland? In: Renard G, Neef A, Becker K, von Oppen M (eds) Soil fertility Management in West African Land use Systems. Proceedings of the Regional Workshop. Margraf Verlag, Weikersheim, pp 361-367

Schlesinger WH, Bernhardt ES (2013) Biogeochemistry: an analysis of global change, Third edn. Academic Press, Waltham

Searle KR, Shipley LA (2008) The comparative feeding bahaviour of large browsing and grazing herbivores. In: Gordon IJ, Prins HHT (eds) The ecology of browsing and grazing. Springer, Berlin Heidelberg, pp 117-118

Shriver JA, Carter SD, Sutton AL, Richert BT, Senne BW, Pettey LA (2003) Effects of adding fiber sources to reduced-crude protein, amino acid-supplemented diets on nitrogen excretion, growth performance, and carcass traits of finishing pigs. J Anim Sci 81:492-502. https://doi.org/10.2527 /2003.812492x

Sierra J, Desfontaines L, Faverial J, Loranger-Merciris G, Boval M (2013) Composting and vermicomposting of cattle manure and green wastes under tropical conditions: carbon and nutrient balances and end-product quality. Soil Res 51:142151. https://doi.org/10.1071/SR13031

Somda ZC, Powell JM (1998) Seasonal decomposition of sheep manure and forage leaves in soil. Commun Soil Sci Plant Anal 29:2961-2979. https://doi.org/10.1080 /00103629809370169

Stark CH, Condron LM, O’Callaghan M, Stewart A, di HJ (2008) Differences in soil enzyme activities, microbial community structure and short-term nitrogen mineralisation resulting from farm management history and organic matter amendments. Soil Biol Biochem 40:1352-1363. https://doi. org/10.1016/j.soilbio.2007.09.025

Strickland MS, Osburn E, Lauber C, Fierer N, Bradford MA (2009) Litter quality is in the eye of the beholder: initial decomposition rates as a function of inoculum characteristics. Funct Ecol 23:627-636. https://doi.org/10.1111/j.13652435.2008.01515.x

Tanentzap AJ, Coomes DA (2012) Carbon storage in terrestrial ecosystems: do browsing and grazing herbivores matter? Biol Rev 87:72-94. https://doi.org/10.1111/j.1469-185 X.2011.00185.x

Thornton PK, Herrero M (2014) Climate change adaptation in mixed crop-livestock systems in developing countries. Glob Food Sec 3:99-107. https://doi.org/10.1016/j. gfs.2014.02.002

Valdés-Correcher E, Sitters J, Wassen M, Brion N, Olde Venterink H (2019) Herbivore dung quality affects plant community diversity. Sci Rep 9:1-6. https://doi.org/10.1038/s41598019-42249-z

Van Soest PJ (1963) Use of detergents in the analysis of fibrous feeds II A rapid method for the determination of fiber and lignin. J Assoc Off Ana Chem 46:829-835

Van Soest PJ, Robertson JB, Lewis BA (1991) Methods for dietary fiber, neutral detergent fiber, and nonstarch polysaccharides in relation to animal nutrition. J Dairy Sci 74:3583-3597. https://doi.org/10.3168/jds.S0022-0302(91)78551-2

Veen GFC, Freschet GT, Ordonez A, Wardle DA (2015) Litter quality and environmental controls of home-field advantage effects on litter decomposition. Oikos 124:187-195. https://doi.org/10.1111/oik.01374

Wall DH, Bradford MA, St. John MG et al (2008) Global decomposition experiment shows soil animal impacts on decomposition are climate-dependent. Glob Chang Biol 14:26612677. https://doi.org/10.1111/j.1365-2486.2008.01672.x

Wang C, Wang X, Liu D, Wu H, Lü X, Fang Y, Cheng W, Luo W, Jiang P, Shi J, Yin H, Zhou J, Han X, Bai E (2014) Aridity threshold in controlling ecosystem nitrogen cycling in arid and semi-arid grasslands. Nat Commun 5:4799. https://doi. org/10.1038/ncomms5799

Wang S, Ruan H, Han Y (2010) Effects of microclimate, litter type, and mesh size on leaf litter decomposition along an elevation gradient in the Wuyi Mountains, China. Ecol Res 25:1113-1120. https://doi.org/10.1007/s11284-010-0736-9 
Wang S, Ruan H, Wang B (2009) Effects of soil microarthropods on plant litter decomposition across an elevation gradient in the Wuyi Mountains. Soil Biol Biochem 41:891-897. https://doi.org/10.1016/j.soilbio.2008.12.016

Ward GN, Kelly KB, Hollier JW (2018) Greenhouse gas emissions from dung, urine and dairy pond sludge applied to pasture. 1. Nitrous oxide emissions. Anim Prod Sci 58: 1087-1093. https://doi.org/10.1071/AN15595

Wardle DA, Bardgett RD, Klironomos JN et al (2004) Ecological linkages between aboveground and belowground biota. Science 304(80):1629-1633

Wieder WR, Bonan GB, Allison SD (2013) Global soil carbon projections are improved by modelling microbial processes. Nat Clim Chang 3:909-912. https://doi.org/10.1038 /nclimate1951

Wilkinson DM (2006) Fragments of an entangled bank: do ecologists study most of ecology? Oikos 82:393. https://doi. org/10.2307/3546981

Xu Y, Chen Z, Fontaine S, Wang W, Luo J, Fan J, Ding W (2017) Dominant effects of organic carbon chemistry on decomposition dynamics of crop residues in a Mollisol. Soil Biol Biochem 115:221-232. https://doi.org/10.1016/j. soilbio.2017.08.029

Yue K, Yang W, Peng Y et al (2015) Study type and plant litter identity modulating the response of litter decomposition to warming, elevated $\mathrm{CO}_{2}$, and elevated $\mathrm{O}_{3}$ : a meta-analysis. $\mathrm{J}$
Geophys Res Biogeosci 120:441-451. https://doi. org/10.1002/2014JG002885

Zechmeister-Boltenstern S, Keiblinger KM, Mooshammer M, Peñuelas J, Richter A, Sardans J, Wanek W (2015) The application of ecological stoichiometry to plant-microbialsoil organic matter transformations. Ecol Monogr 85:133155. https://doi.org/10.1890/14-0777.1

Zhou G, Luo Q, Chen Y, et al (2018) Effects of livestock grazing on grassland carbon storage and release override impacts associated with global climate change. Glob Chang biol 115. https://doi.org/10.1111/gcb.14533

Zhu Y, Merbold L, Leitner S, Xia L, Pelster DE, Diaz-Pines E, Abwanda S, Mutuo PM, Butterbach-Bahl K (2020) Influence of soil properties on $\mathrm{N}_{2} \mathrm{O}$ and $\mathrm{CO}_{2}$ emissions from excreta deposited on tropical pastures in Kenya. Soil Biol Biochem 140:107636. https://doi.org/10.1016/j.soilbio.2019.107636

Zhu Y, Merbold L, Pelster D, Diaz-Pines E, Wanyama GN, Butterbach-Bahl K (2018) Effect of dung quantity and quality on greenhouse gas fluxes from tropical pastures in Kenya. Glob Biogeochem Cycles 32:1589-1604. https://doi. org/10.1029/2018GB005949

Publisher's note Springer Nature remains neutral with regard to jurisdictional claims in published maps and institutional affiliations. 